\title{
TUGAS DAN WEWENANG OMBUDSMAN REPUBLIK INDONESIA DALAM PELAYANAN PUBLIK MENURUT UU NO. 37 TAHUN 2008
}

\author{
Setiajeng Kadarsih \\ Fakultas Hukum Universitas Jenderal Soedirman, Purwokerto, Jawa Tengah
}

\begin{abstract}
Ombudsman $R I$ is an institute that has an autonomy and it doesn't have organic relationship with other state and governance institutes and also it runs its duties and rights free from the involvement of other authority. This institute has right to control the establishment of public service. Ombudsman's right detail exists in Article 8 Law Number 37Year 2008 concerning ombudsman RI. Besides, OMBUDSMAN is allowed to give advice to the government to make reparation and perfection of organization and procedures of public service in order to avoid administration problem.
\end{abstract}

Keywords: duty, right, public service

\begin{abstract}
Abstrak
Ombudsman Republik Indonesia adalah lembaga yang memiliki kemandirian, tidak memiliki hubungan organik dengan negara dan lembaga-lembaga pemerintahan lain dan juga saat menjalankan tugas bebas dari keterlibatan lembaga lainnya. Lembaga ini memiliki hak untuk mengontrol pelayanan publik. hak Ombudsman terdapat dalam Pasal 8 Undang-Undang Nomor 37 Tahun 2008 tentang Ombudsman Republik Indonesia. Selain itu, Ombudsman diperbolehkan untuk memberikan nasihat kepada pemerintah untuk melakukan perbaikan dan penyempurnaan organisasi dan prosedur pelayanan publik dalam rangka untuk menghindari masalah administrasi.
\end{abstract}

Kata kunci: tugas, hak, pelayanan publik

\section{Pendahuluan}

Negara hukum adalah negara yang menggunakan instrumen hukum sebagai landasan tindakan dan perbuatan penguasa maupun warga negaranya, sehingga dasar legalitasnya berdasarkan hukum tertulis maupun tidak tertulis. Negara hukum menempatkan hukum sebagai dasar kekuasaan negara dan penyelenggaraan kekuasaan tersebut dalam segala bentuknya serta menggunakan hukum dalam menjamin keadilan bagi warga negaranya. ${ }^{1}$

Pelayanan kepada masyarakat dan penegakan hukum juga dilakukan dalam rangka penyelenggaraan negara dan pemerintahan merupakan bagian yang tidak terpisahkan dari upaya untuk menciptakan pemerintahan yang lebih

\footnotetext{
1 Weda Kupita, 2007, Peranan Komisi Ombudsman Nasional dalam Penegakan Hukum dan Pelayanan Umum Pemerintahan (Eksistensi Ombudsman dalam Lintasan Sejarah), Purwokerto: Universitas Jenderal Soedirman
}

baik, bersih, dan efisien guna mening-katkan kesejahteraan serta menciptakan keadilan dan kepastian hukum bagi seluruh warga negara sebagaimana dimaksud dalam UUD Negara RI tahun 1945. Oleh karena itu pengawasan pelayanan yang diselenggarakan oleh penyelenggaraan negara dan pemerintahan merupakan unsur penting dalam upaya menciptakan Good Governance.

Aspirasi yang berkembang dalam masyarakat mengharapkan agar terwujud aparatur penyelenggara negara dan pemerintahan yang efektif dan efisien, jujur, bersih, terbuka serta bebas dari korupsi, kolusi, dan nepotisme, maka perlu dibentuk lembaga negara yang mengawasi penyelenggaraan pelayanan publik, karena sudah cukup lama Bangsa Indonesia ini merasa tidak puas terhadap lembaga birokrasi pemerintahan, namun keluhan-keluhan atas ketidakpuasan tersebut tidak ditanggapi dan pada 
saat yang sama sistem penegakan hukum (yang menjadi tujuan akhir memperoleh keadilan) sangat lamban, mahal, bersifat publik, dan jauh dari kemudahan (not user friendly). Karena itulah Bangsa Indonesia mendambakan perubahan dalam penyelenggaraan pemerintahan dan pelayanan publik menjadi pemerintahan yang bersih, efisien, dan ramah terhadap kepentingan masyarakat. $^{2}$

Undang-undang Republik Indonesia No. 25 tahun 2009 tentang Pelayanan Publik sudah di undangkan pada tanggal 18 Juli 2009, yang di maksud dengan pelayanan publik adalah kegiatan atau rangkaian kegiatan dalam rangka pemenuhan kebutuhan pelayanan masyarakat sesuai dengan peraturan perundang-undangan yang berlaku bagi setiap warga negara dan penduduk atas barang, jasa, dan atau pelayanan SDM yang disediakan oleh penyelenggara pelayanan publik.

Dalam kaitan ini, masyarakat mempunyai hak berupa, kesatu, mendapatkan pelayanan yang berkualitas sesuai dengan asas dan tujuan pelayanan; kedua, mengetahui sistem, mekanisme, dan prosedur pelayanan; ketiga, mendapat tanggapan atas keluhan yang diajukan secara layak dan mendapatkan advokasi, perlindungan dan pemenuhan pelayanan.

Di samping hak, masyarakat mempunyai kewajiban sesuai dengan UU Pelayanan Publik, yaitu mengawasi dan memberitahukan kepada penyelenggaraan untuk memperbaiki pelayanan apabila pelayanan yang diberikan tidak sesuai dengan standar pelayanan yang berlaku; melaporkan penyimpangan pelaksanaan pelayanan kepada Ombudsman apabila penyelenggaraan tersebut tidak memperbaiki pelayanan; mematuhi dan memenuhi persyaratan, sistem, dan mekanisme prosedur dalam mendapatkan pelayanan; dan menjaga dan turut memelihara sarana dan prasara pelayanan umum dan berpartisipasi aktif dan mematuhi segala keputusan penyelenggara.

Pengawasan penyelenggaraan pelayanan publik dilakukan oleh pengawas intern dan pengawas ekstern. Pengawasan intern penyelenggaraan pelayanan publik dilakukan melalui peng-

2 www.Ombudsman.go.id., diakses tanggal 20 November 2008 awasan oleh atasan langsung sesuai dengan peraturan perundang-undangan dan pengawasan oleh aparat pengawasan fungsional sesuai denga peraturan perundang-undangan. Sedangkan pengawasan ekstern penyelenggaraan pelayanan publik dilakukan melalui pengawasan oleh ombudsman dan pengawasan masyarakat.

Berdasarkan uraian latar belakang diatas, malka tulisan ini dimkasudkan untuk mengetahui mengenai tugas dan wewenang Ombudsman Republik Indonesia dalam penyelenggaraan pelayanan publik.

\section{Pembahasan}

\section{Asal Usul Ombudsman}

Institusi pengawasan yang bernama "Ombudsman" pertama kali lahir di Swedia, namun demikian sebenarnya Swedia bukanlah negara pertama yang membangun sistem pengawasan Ombudsman. Pada zaman Romawi telah terdapat institusi "Tribunal Plebis" yang tugasnya hampir sama dengan Ombudsman yaitu melindungi hak masyarakat lemah dan penyalahgunaan kekuasaan oleh para bangsawan. Model yang demikian juga dapat dijumpai pada Kekaisaran Cina Dinasty Tsin tahun 221 SM. ${ }^{3}$

Sebagai suatu institusi yang secara tegas melembaga, sistem Ombudsman justru sebenarnya pertama kali dikenal pada masa Kekalifahan Islam. Menurut Dean M. Gottehrer, mantan Presiden Asosiasi Ombudsman Amerika Serikat, menemukan bahwa pada dasarnya Ombudsman berakar dari prinsip-prinsip keadilan yang menjadi bagian dari mekanisme pengawasan dalam sistem ketatanegaraan Islam, hal ini dapat di lihat pada masa Kalifah Umar Bin Khatab (634 644) yang pada masa itu memposisikan diri sebagai "Muhtasib" yaitu orang yang menerima keluhan dan juga menjadi mediator dalam mengupayakan proses penyelesaian perselisihan antara masyarakat dengan pejabat pemerintah. Tugas sebagai

Muhtasib dilakukan secara langsung oleh Umar Bin Khatab dengan cara mendengar se-

\footnotetext{
3 Jeremi Pope, 1999, Pengembangan Sistem Integritas Nasional, Jakarta: Pustaka Utama Grafiti, hlm.115
} 
cara langsung keluhan dari rakyat. ${ }^{4}$ Umar bin Khatab kemudian membentuk lembaga Qadi Al Quadat (Ketua Hakim Agung) dengan tugas khusus melindungi warga masyarakat dari tindakan sewenang-wenang dan penyalahgunaan kekuasaan oleh pejabat pemerintah. ${ }^{5}$

\section{Sejarah Parliamentary Ombudsman Swedia}

Ide pembentukan Ombudsman datang dari Keputusan Raja Charles XII (1697-1718) dengan membentuk Office of The King's Highest Ombudsman. Keputusan Raja Charles XII ini terpengaruh oleh sistem Turkish Office of Chief Justice (Chief Justice). Pada sistem ketatanegaraan Turki, Chief Justice sangat berperan melakukan pengawasan terhadap penyelenggaraan negara guna menjamin ditaatinya hukum Islam oleh seluruh penyelenggara negara, termasuk Sultan sebagai pemimpin tertinggi.

Chief Justice di Turki juga bertugas melindungi hak-hak rakyat yang diperlakukan tidak adil oleh penguasa. Keberadaan Chief Justice berpengaruh terhadap penegakan hukum dalam sistem ketatanegaraan Turki, mekanisme chek and balance seperti ini yang mengilhami Raja Charles XII membentuk Hights Ombudsman di Swedia. Pembentukan Hights Ombudsman oleh Raja Charles XII dapat dinilai sebagai kerelaan Raja membuka ruang pengawasan oleh masyarakat terhadap jalannya roda pemeritahan, serta Raja itu sendiri rela diawasi oleh masyarakat. ${ }^{6}$

Setelah Raja Charles wafat, Hights Ombudsman, berganti nama menjadi the Offce of Chancellor of Justice (Chancellor of Justice), yang dipilih oleh Tuan Tanah (Estate), yang kemudian selanjutnya berubah dipilih oleh Parlemen, yang bertugas antara lain menjamin hakhak publik, perlidungan individu, serta mengawasi ketaatan hakim dan pejabat negera terhadap hukum, mencegah dan menindak maladministrasi. $^{7}$

\footnotetext{
4 Dean M. Gotteher, 2000, International Update, The Second Ombudsman Leadership, San Fransisco: Forum Conference, hlm. 14.

5 Bryan Gilling, 1998, The Ombudsmanin New Zealand, Welington: Dunmore Press, hlm. 67

6 Budi Masthuri, 2005, Mengenal Ombudsman Indonesia, Jakarta: Pradnya Paramita, hlm 4

7 Bengt Wieslander, 1999, The Parliamentary Ombudsman In Sweden, Sodertalje: Fringraf
}

Pada tahun 1809 Swedia secara resmi mencantumkan Ombudsman Parlementer dalam Konstitusi. Kewenangan Ombudsman ini antara lain memiliki kewenangan penuntutan terhadap tindakan maladministrasi (malfeasance) yang di lakukan oleh hakim dan pejabat negara lainnya. Pada tahun 1915 dibentuk Ombudsman Militer, kemudian pada tahun 1968 Ombudsman Parlementer dan Militer digabung men jadi satu.

\section{Berbagai Jenis Ombudsman}

Pada mulanya institusi Ombudsman di kenal di Swedia, dan baru satu setengah abad belakangan ini di sistem Ombudsman menyebar ke berbagai penjuru dunia. ${ }^{8}$ Ombudsman Parlementer kedua dibentuk tahun 1919 di Finlandia, dan tahun 1955 di Denmark. Sistem Ombudsman telah mencantumkan institusi Ombudsman ke dalam konstitusinya. ${ }^{9}$

Berdasarkan beberapa aspek, Ombudsman dapat dibagi menjadi beberapa jenis. ${ }^{10}$ Dari kurun waktu pembentukannya, dapat dibedakan menjadi Ombudsman Klasik dan Ombudsman Modern. Ombudsman Klasik dapat ditelusuri sejak pertama kali Raja Charles XII membentuk Highest Ombudsman, Chief Justice di Turki dan Qadi Al Quadat zaman Umar Bin Khatab. Ombudsman Modern berdiri sejak tahun 1953 di Denmark dan 1962 di New Zealand. Ombudsman Parlementer di Swedia dikategorikan sebagai Ombudsman Modern.

Apabila dilihat dari mandat dan mekanisme pertanggungjawabannya, dibedakan menjadi dua jenis, yakni pertama, Ombudsman Parlementer, yakni Ombudsman yang dipilih oleh Parlemen, dan bertanggung jawab (laporan) kepada Parlemen. Contohnya Swedia, Finlandia, dan Denmark; dan kedua, Ombudsman Eksekutif, yakni yang dipilih oleh presiden, Perdana Men-teri, atau Kepala Daerah. Contohnya Indonesia dan Australia.

\footnotetext{
8 Antonius Sujata dan Surachman, 2002, Ombudsman Indonesia di Tengah Ombudsman Internasiona, Jakarta: Komisi Ombudsman Indonesia, hlm. 29.

9 Budi Masthuri; Urgensi Pengaturan Ombudsman Dalam Konstitusi, diakses dalam www.hukumonline.com tanggal 30 September 2004

${ }^{10}$ Budi Masthuri, op. cit., hlm 6-8
} 
Apabila dilihat dari isu dan institusi yang membentuk, maka ombudsman dibagi menjadi tiga. Pertama, Ombudsman Publik, yakni dibentuk oleh institusi publik untuk mengawasi proses pemberian pelayanan umum bagi masyarakat sebuah negara. Contohnya Indonesia dan Irlandia Utara, dan Thailand. Kedua, Ombudsman Swasta, yakni dibentuk oleh swasta untuk melayani proses pelayanan umum perusahaan swasta terhadap konsumennya. Contohnya Ombudsman Perusahaan Asuransi, Real Estate. Ketiga, Ombudsman Hibryd, yakni yang dibentuk oleh swsta atas mandat yang diberikan oleh negara untuk mengawasi proses pelayanan umum di sektor swasta. Pada dasarnya ini merupakan Ombudsman Swasta, tetapi keberadaannya di amanatkan oleh negara dengan undang-undang tertentu. Contohnya Ombudsman Pers di Swedia.

Apabila dilihat dari batas wilayah yurisdiksinya, maka ombudsman dibagi menjadi tiga juga. Pertama, Ombudsman Nasional, yakni yang wilayah kerjanya menyangkut seluruh wilayah negara di mana Ombudsman itu berada. Contohnya Kkomisi Ombudsman Indonesia, Ombudsman Australia. Kedua, Ombudsman Daerah, yakni wilayah kerjanya hanya terbatas pada daerah tertentu saja di sebuah negara. Contohnya Ombudsman Yogyakarta, Pangkal Pinang dan lainlain. Ketiga, Ombudsman Multinasional, yakni yang wilayah kerjanya meliputi beberapa negara. Ombudsman ini dibentuk atas kesepakatan masing-masing negara akan perlunya membangun sistem pengawasan bersama. Contohnya Ombudsman Eropa.

\section{Pengawasan}

Pengawasan adalah salah satu fungsi organik manajemen, yang merupakan proses kegiatan pimpinan untuk memastikan dan menjamin bahwa tujuan dan sasaran serta tugas-tugas organisasi akan dan telah terlaksana dengan baik sesuai dengan rencana, kebijaksanaan, instruksi, dan ketentuan-ketentuan yang telah ditetapkan dan yang berlaku. Hakikat pengawasan adalah untuk mencegah sedini mungkin terjadinya penyimpangan, pemborosan, penyelewengan, hambatan, kesalahan dan kegagalan dalam pencapai- an tujuan dan sasaran serta pelaksanaan tugastugas organisasi. ${ }^{11}$

Di dalam buku Diana H.K., Lord Action menyatakan bahwa setiap kekuasaan sekecil apapun cenderung untuk disalahgunakan. Dengan adanya keleluasaan bertindak dari administrasi negara yang memasuki semua sektor kehidupan masyarakat, terkadang dapat menimbulkan kerugian bagi masyarakat itu sendiri, maka wajar apabila diadakan pengawasan terhadap jalannya pemerintahan, yang merupakan jaminan agar jangan sampai keadaan negara menjurus ke arah diktator tanpa batas, yang bertentangan dengan ciri negara hukum. Pada sisi lain berarti pula ada suatu sistem perlindungan bagi yang diperintah oleh karena adanya tindakan diskresi (freies ermessen) serta perlindungan terhadap administrasi negara itu sendiri agar sikap dan tindakannya baik dan benar menurut hukum, baik yang tertulis maupun yang tidak tertulis.

Cara-cara pengawasan dalam penyelenggaraan pemerintahan dapat diperinci sebagai berikut. Pertama, ditinjau dari kedudukan badan/organ yang melaksanakan pengawasan, ma-ka cara pengawasannya adalah pengawasan intern dan ekstern. Kedua, ditinjau dari segi saat/waktu dilaksanakannya maka terdapat pengawasan preventif/pengawasan apriori dan pengawasan represif/pengawasan aposteriori. Ketiga, pengawasan dari segi hukum.

Pengawasan adalah proses kegiatan-kegiatan yang membandingkan apa yang dijalankan, dilaksanakan, atau diselenggarakan itu dengan apa yang dikehendaki, direncanakan, atau diperintahkan. Hasil pengawasan ada yang mempunyai akibat hukum, namun sebagian besar bersifat politis, administratif (ketatausahaan, organisasional, manajerial, operasional), atau teknis-fungsional. ${ }^{12}$

\footnotetext{
11 Lembaga Administrasi Negara Republik Indonesia, 1997, Sistem Administrasi Negara Republik Indonesia, Jilid II, Edisi Ketiga, Jakarta: PT. Gunung Agung, hlm. 159

12 Prajudi Atmosudirdja, 1994, Hukum Administrasi Negara, Jakarta: Ghalia Indonesia,. hlm. 84-85
} 


\section{Kewenangan}

Menurut Kamus Besar Bahasa Indonesia, kewenangan adalah hak dan kekuasaan yang dipunyai untuk melakukan sesuatu. Kewenangan (yang biasanya terdiri atas beberapa wewenang) adalah kekuasaan terhadap segolongan orangorang tertentu atau kekuasaan terhadap sesuatu bidang pemerintahan (atau bidang urusan) tertentu yang bulat, sedangkan wewenang hanya mengenai sesuatu onderdil tertentu saja. ${ }^{13}$

Wewenang adalah memiliki arti yaitu kemampuan melakukan tindakan hukum tertentu. Dalam buku Ridwan H.R., H.D. Stout menyatakan bahwa wewenang adalah pengertian yang berasal dari hukum organisasi pemerintahan, yang dapat dijelaskan sebagai keseluruhan aturanaturan yang berkenaan dengan perolehan dan penggunaan wewenang pemerintahan oleh subjek hukum publik dalam hubungan hukum publik.

Ridwan H.R. juga mengutip pendapat dari Bagir Manan, bahwa wewenang dalam bahasa hukum tidak sama dengan kekuasaan (macht). Kekuasaan hanya menggambarkan hak untuk berbuat atau tidak berbuat, sedangkan dalam hukum, wewenang sekaligus berarti hak dan kewajiban (rechten en plichten). ${ }^{14}$

Setiap kewenangan dibatasi oleh isi/materi, wilayah dan waktu. Cacat dalam aspek-aspek tersebut menimbulkan cacat kewenangan (onbevoegdheid) yang menyangkut cacat isi (onbevoegdheid ratione materiae); cacat wilayah (onbevoegdheid ratione loci); dan cacat waktu (onbevoegdheid ratione temporis). ${ }^{15}$

\section{Ombudsman Republik Indonesia (ORI)}

Institusi pengawasan bernama Ombudsman pertama kali lahir di Swedia, namun pada dasarnya Swedia bukanlah negara pertama yang membangun sistem pengawasan Ombudsman. Bryan Gilling dalam tulisannya berjudul "The Ombudsman In New Zealand" mengungkapkan bahwa pada zaman Kekaisaran Romawi terdapat institusi Tibunal Plebis yang tugasnya hampir sama dengan Ombudsman yaitu melindungi hak-

\footnotetext{
${ }^{13}$ Ibid., hlm. 78

${ }^{14}$ Ridwan H.R., op. cit., hlm. 101-102

${ }^{15}$ Surachmad, et.al., 2004, Buku Ajar Mata Kuliah Hukum Administrasi Negara, Purwokerto: Universitas Jenderal Soedirman, hlm. 24-25
}

hak masyarakat lemah dari penyalahgunaan kekuasaan oleh para bangsawan. ${ }^{16}$

Di Indonesia sendiri pembentukan Komisi Ombudsman Nasional (Ombudsman) dilatorbelakangi oleh suasana transisi menuju demokrasi. Pada saat itulah Gus Dur sebagai Presiden Republik Indonesia memutuskan membentuk Ombudsman sebagai lembaga yang diberi wewenang mengawasi kinerja pemerintahan (termasuk dirinya sendiri) dan pelayanan umum lembaga peradilan, ${ }^{17}$ dengan menandatangani Keputusan Presiden Nomor 44 Tahun 2000 tentang Komisi Ombudsman Nasional pada tanggal 20 Maret 2000. Sejak tanggal 07 Oktober 2008 Komisis Ombudsman Nasional (KON) telah berganti nama menjadi Ombudsman Republik Indonesia (ORI) seiring dengan disahkannya Undang-Undang Nomor 37 Tahun 2008 tentang Ombudsman Republik Indonesia oleh Presiden Republik Indonesia Susilo Bambang Yudhoyono.

Menurut Pasal 2 Keputusan Presiden Nomor 44 Tahun 2000 tentang Komisi Ombudsman Nasional, yang dimaksud dengan ombudsman nasional adalah lembaga pengawasan masyarakat yang berasaskan Pancasila dan bersifat mandiri, serta berwenang melakukan klarifikasi, monitoring atau pemeriksaan atas laporan masyarakat mengenai penyelenggaraan negara khususnya pelaksanaan oleh aparatur pemerintahan termasuk lembaga peradilan terutama dalam memberikan pelayanan kepada masyarakat."

Sedangkan menurut pasal 1 angka 1 Undang-Undang Nomor 37 Tahun 2008 tentang Ombudsman Republik Indonesia, yang dimaksud dengan Ombudsman Republik Indonesia yang selanjutnya disebut ombudsman adalah lembaga negara yang mempunyai kewenangan mengawasi penyelenggaraan pelayanan publik baik yang diselenggarakan oleh penyelenggara negara dan pemerintahan termasuk yang diselenggarakan oleh Badan Usaha Milik Negara, Badan Usaha Milik Daerah, dan Badan Hukum Milik Negara serta badan swasta atau perseorangan yang diberi tugas menyelenggarakan pelayanan

\footnotetext{
${ }^{16}$ Budhi Masthuri, op.cit, hal. 1-2

17 Ibid., hal. 8
} 
publik tertentu yang sebagian atau seluruh dananya bersumber dari anggaran pendapatan dan belanja negara dan/atau anggaran pendapatan belanja daerah."

Tujuan dibentuknya ORI adalah mewujudkan negara hukum yang demokratis, adil, dan sejahtera; mendororng penyeleng-garaan negara dan pemerintahan yang efektif dan efisien, jujur, terbuka, bersih, serta bebas korupsi, kolusi, dan nepotisme; meningkatkan mutu pelayanan negara di segala bidang agar setiap warga negara dan penduduk memperoleh keadilan, rasa aman, dan kesejahteraan yang semakin baik; membantu menciptakan dan meningkatkan upaya untuk pemberantasan dan pencegahan praktikpraktik maladministrasi, diskriminasi, kolusi, korupsi, serta nepotisme; meningkatkan budaya hukum nasional, kesadaran hukum masyarakat, dan supremasi hukum yang berintikan kebenaran serta keadilan.

Dalam menjalankan kewena-ngannya ORI berpegang pada asas mendengarkan kedua belah pihak serta tidak menerima imbalan apapun baik dari masyarakat yang melapor ataupun instansi yang dilaporkan. Ombudsman tidak menyibukkan diri dengan perlindungan hukum dalam arti yang sesungguhnya, namun dia menguji tindakan-tindakan atas norma-norma kepantasan. ${ }^{18}$

\section{Maladministrasi}

Menurut pasal 1 angka 1 Undang-Undang Nomor 37 Tahun 2008 tentang Ombudsman Republik Indonesia, yang dimaksud dengan maladministrasi adalah perilaku atau perbuatan melawan hukum, melampaui wewenang, menggunakan wewenang untuk tujuan lain dari yang menjadi tujuan wewenang tersebut, termasuk kelalaian atau pengabaian kewajiban hukum dalam penyelenggaraan pelayanan publik yang dilakukan oleh Penyelenggara Negara dan pemerintahan yang menimbulkan kerugian materiil dan/atau immateriil bagi masyarakat dan orang perseorangan.

\footnotetext{
18 Philipus M. Hadjon, et.al, 1999, Pengantar Hukum Administrasi Indonesia. (Introduction to The Indonesian Administrative Law). Yogyakarta: Gadjah Mada Univer-sity Press,. hlm. 303
}

Pengertian maladministrasi secara umum adalah perilaku yang tidak wajar (termasuk penundaan pemberi pelayanan), tidak sopan dan kurang peduli terhadap masalah yang menimpa seseorang disebabkan oleh perbuatan penyalahgunaan kekuasaan, termasuk penggunaan kekuasaan secara semena-mena atau kekuasaan yang digunakan untuk perbuatan yang tidak wajar, tidak adil, intimidatif atau diskriminatif dan tidak patut didasarkan sebagian atau seluruhnya atas ketentuan undangundang atau fakta, serta tidak masuk akal. ${ }^{19}$

Maladministrasi adalah suatu praktik yang menyimpang dari etika administrasi, atau suatu praktik administrasi yang menjauhkan dari pencapaian tujuan administrasi. Terminologi dari maladministrasi dipahami lebih luas dari sekadar penyimpangan yang bersifat ketatabukuan. Meskipun Demikian, maladministrasi juga harus dipahami tidak sekadar sebagai penyimpangan terhadap hal tulis-menulis, tata buku, dan sebagainya, tetapi lebih luas mencakup penyimpangan terhadap fungsi-fungsi pelayanan publik yang dilakukan setiap penyelenggara negara (termasuk anggota parlemen) kepada masyarakat.

Secara lebih umum maladministrasi di artikan sebagai penyimpangan, pelanggaran atau mengabaikan kewajiban hukum dan kepatutan masyarakat sehingga tindakan yang dilakukan tidak sesuai dengan asas umum pemerintahan yang baik (good governance). Dengan demikian dapat disimpulkan bahwa parameter yang di jadikan sebagai ukuran maladministrasi adalah peraturan hukum dan kepatutan masyarakat serta asas umum pemerintahan yang baik.

Dalam buku Budhi Masthuri, Crossman mengklasifikasikan bentuk tindakan yang dapat dikategorikan sebagai maladministrasi, yaitu: berprasangka, kelalaian, kurang peduli, keterlambatan, bukan kewenangan, tindakan tidak layak, jahat, kejam, dan semena-mena. ${ }^{20}$

\section{Pengertian Kewenangan}

Asas legalitas merupakan suatu prinsip utama dalam setiap negara hukum, merupakan

\footnotetext{
19 Ibid., hlm. 6

20 Budhi Masthuri, op. cit., hlm. 43-45
} 
dasar dalam setiap penyelenggaraan kenegaraan dan pemerintahan. Dengan kata lain, setiap penyelenggaraan kenegaraan dan pemerintahan harus memiliki legitimasi yaitu kewenangan yang diberikan oleh Undang-Undang. Dengan demikian, substansi asas legalitas adalah wewenang, yaitu kemampuan untuk melakukan tindakantindakan hukum tertentu. ${ }^{21}$ Menurut Kamus Besar Bahasa Indonesia kewenangan berasal dari kata "wewenang" yang berarti hak dan kekuasaan untuk bertindak. Kewenangan adalah kekuasaan membuat keputusan memerintah dan melimpahkan tanggung jawab kepada orang lain.

Definisi kewenangan menurut F. P. C. L Tonnaer yaitu kewenangan pemerintah dalam kaitan ini dianggap sebagai kemampuan untuk melaksanakan hukum positif, dan dengan be-gitu dapat diciptakan hubungan hukum antara pemerintah dengan warga negara.

Kewenangan memiliki kedudukan penting dalam kajian hukum tata Negara dan hukum administrasi. Begitu pentingnya kedudukan kewenangan ini, sehingga F.A.M. Stroink dan J.G. Steenbeek menyebutnya sebagai konsep inti dalam hukum tata negara dan hukum administrasi. Kewenangan yang di dalamnya terkandung hak dan kewajiban, menurut P. Nicola kewenangan adalah kemampuan untuk melakukan tindakan hukum tertentu, yaitu tindakan-tindakan yang dimaksudkan untuk menimbulkan akibat hukum dan mencakup mengenai timbulnya dan lenyapnya akibat hukum tertentu, hak berisi kebebasan untuk melakukan atau tidak melakukan tindakan tertentu atau menuntut pihak lain untuk melakukan tindakan tertentu, sedangkan kewajiban memuat keharusan untuk melakukan atau tidak melakukan tindakan tertentu. ${ }^{22}$

\section{Macam-macam cara memperoleh kewenangan}

Secara teoritik kewenangan yang ber-sumber dari peraturan perundang-undangan tersebut diperoleh melalui 3 (tiga) cara, yaitu atribusi, delegasi, dan mandat. Mengenai hal ini H.D. Van Wijk/Willem Konijnenbelt dalam bukunya Ridwan HR, mendefinisikan ketiga cara perolehan kewenangan. Attributie didefinisikan sebagai

${ }^{21}$ Ridwan, HR, op. cit., hlm 70

22 Ibid., hlm. 71-72 toekening van een besstuursbevoegheid door een wetgever aan een bestuursorgaan, (Atribusi adalah pemberian wewenang pemerintah oleh pembuat Undang-Undang kepada Pemerintahan). Delegatie didefinisikan sebagai overdracht van een bevoigheid van het ene bestuursorgaan aan een ander, (Delegasi adalah pelimpahan wewenang Pemerintahan dari satu Organ Pemerintahan kepada Organ Pemerintah lainnya). Mandaat didefinisikan sebagai een bestuursorgaanlaat zijn bevoigheid namens hem uitoemfenen door een ander, (Mandat terjadinya ketika organ pemerintahan mengijinkan kewenangannya dijalankan oleh organ lainnya atas namanya). ${ }^{23}$

Kewenangan Pemerintah Provinsi sesuai dengan kedudukannya sebagai daerah otonom menjadi penyelenggara kewenangan Pemerintahan otonom yang bersifat lintas kabupaten/ kota dan kewenangan pemerintahan lainnya. Sementara itu kewenangan provinsi sebagai wilayah administrasi merupakan pelaksanaan kewenang-an pemerintah yang didekonsentrasikan kepada Gubernur (Dilimpahkan kepada Gubernur sebagai wakil pemerintahan.

\section{Teori Kewenangan}

Kewenangan atau wewenang adalah suatu istilah yang biasa digunakan dalam lapangan hukum publik. Namun sesungguhnya terdapat perbedaan di antara keduanya. Kewenangan adalah apa yang disebut "kekuasaan formal", kekuasaan yang berasal dari kekuasaan yang diberikan oleh Undang-Undang atau legislatif dari kekuasaan eksekutif atau administratif. Karenanya, merupakan kekuasaan dari segolongan orang tertentu atau kekuasaan terhadap suatu bidang pemerintahan atau urusan pemerintahan tertentu yang bulat. Sedangkan wewenang hanya mengenai suatu bagian tertentu saja dari kewenangan. Wewenang (authority) adalah hak untuk memberi perintah, dan kekuasaan untuk meminta dipatuhi.

Menurut Bagir Manan, wewenang dalam bahasa hukum tidak sama dengan kekuasaan (macht). Kekuasaan hanya menggambarkan hak

${ }^{23}$ Ibid., hlm. 74 
untuk berbuat atau tidak berbuat. Dalam hukum, wewenang sekaligus berarti hak dan kewajiban (rechten en plichten). Hak mengandung pengertian kekuasaan untuk mengatur sendiri (zelfregelen) dan mengelola sendiri (zelfbesturen), sedang-kan kewajiban secara horizontal berarti kekuasaan untuk menyelenggarakan pemerintahan sebagaimana mestinya. Vertikal berarti kekuasaan untuk menjalankan pemerintahan dalam satu tertib ikatan pemerintahan negara secara keseluruhan. ${ }^{24}$

Menurut Prajudi Atmosudirdjo yang di maksud dengan wewenang adalah kekuasaan untuk melakukan sesuatu tindakan hukum publik, misalnya wewenang menandatangani atau menerbitkan surat-surat ijin dari seorang pejabat atas nama menteri, sedangkan kewenangan tetap berada di tangan Menteri (delegasi wewenang). ${ }^{25}$ Wewenang hukum publik adalah wewenang untuk menimbulkan akibat-akibat hukum yang sifatnya hukum publik, seperti mengeluarkan aturan-aturan, mengambil keputusan-keputusan atau menetapkan suatu rencana dengan akibat-akibat hukum.

Secara teoritik, kewenangan yang bersumber dari peraturan perundangan tersebut di peroleh melalui dua cara yaitu atribusi, dan pelimpahan wewenang yang berupa delegasi dan mandat. Atribusi adalah wewenang yang melekat pada suatu jabatan. Dalam tinjauan hukum tata Negara, atribusi ini ditunjukan dalam wewenang yang dimiliki oleh organ pemerintah dalam menjalankan pemerintahannya berdasarkan kewenangan yang dibentuk oleh pembuat undangundang. Atri-busi ini menunjuk pada kewenangan asli atas dasar konstitusi (UUD) atau peraturan perundang-undangan.

Pelimpahan wewenang adalah penyerahan sebagian dari wewenang pejabat atasan kepada bawahan tersebut membantu dalam melaksanakan tugas-tugas kewajibannya untuk bertindak sendiri. Pelimpahan wewenang ini dimaksudkan untuk menunjang kelancaran tugas dan ketertiban alur komunikasi yang bertanggung jawab, dan sepanjang tidak ditentukan secara khusus oleh peraturan perundang-undangan yang ber- laku, wewenang yang diperoleh melalui proses pelimpahan yang disebut delegasi dan mandat. Pendelegasian diberikan biasanya antara organ pemerintah satu dengan organ pemerintah lain, dan biasanya pihak pemberi wewenang memiliki kedudukan lebih tinggi dari pihak yang di berikan wewenang. Mandat, umumnya diberikan dalam hubungan kerja internal antara atasan dan bawahan.

\section{Penutup}

Simpulan

Ombudsman bertugas menerima Laporan atas dugaan maladministrasi dalam penyelenggaraan pelayanan publik, melakukan pemeriksaan subtansi atas Laporan, menindaklanjuti yang tercakup dalam ruang lingkup kewenangan Om-budsman, dan melakukan tugas lain yang di berikan oleh undang-undang.

Wewenang Ombudsman adalah meminta keterangan secara lisan dan/atau tertulis dari Pelapora, Terlapor, atau pihak lain yang terkait mengenai Laporan yang disampaikan kepada Ombudsman; dan tugas lain sesuai perundangundangan. Ombudsman juga berwenang menyampaikan saran kepada Presiden, Kepala Daerah, atau pimpinan Penyelenggara Negara lainnya guna perbaikan dan penyempurnaan organisasi dan/atau prosedur pelayanan publik; dan menyampaikan saran kepada dewan Perwakilan Rakyat dan/atau Presiden, Dewan Perwakilan Rakyat Daerah dan/atau kepala daerah agar terhadap undang-undang dan peraturan perundang-undangan lainnya diadakan perubahan dalam rangka mencegah maladministrasi.

\footnotetext{
${ }^{24}$ Bagir Manan. op. cit., hlm 1-2

${ }^{25}$ Prajudi Atmosudirdjo, op. cit., hlm. 73-74
} 